American Journal of Biological and Environmental Statistics
2020; 6(3): 43-49
http://www.sciencepublishinggroup.com/j/ajbes
doi: $10.11648 /$ jajbes.20200603.12
ISSN: $2471-9765$ (Print); ISSN: $2471-979 \mathrm{X}$ (Online)

\title{
Physicochemical Quality and Heavy Metals Contamination of Drinking Water Used in Poultry Farms at Maritime Region of Togo
}

\author{
Soumaoro Idrissa $^{1, ~ *}$, Pitala Were ${ }^{1,2}$, Gnandi Kissao ${ }^{3}$, Oke Emmanuel ${ }^{4}$ \\ ${ }^{1}$ Regional Centre of Excellence in Avian Science, University of Lome, Lome, Togo \\ ${ }^{2}$ Department of Animal Production, University of Lome, Lome, Togo \\ ${ }^{3}$ Department of Geology, University of Lome, Lome, Togo \\ ${ }^{4}$ Department of Animal Physiology, Federal University of Agriculture Abeokuta, Abeokuta, Nigeria \\ Email address: \\ Idrissou2020@gmail.com (S. Idrissa),werepit@hotmail.fr (P. Were),kgnandi@yahoo.fr (G. Kissao), \\ emaoke7@yahoo.co.uk (O. Emmanuel) \\ ${ }^{*}$ Corresponding author
}

\section{To cite this article:}

Soumaoro Idrissa., Pitala Were., Gnandi Kissao., Oke Emmanuel. Physicochemical Quality and Heavy Metals Contamination of Drinking Water Used in Poultry Farms at Maritime Region of Togo. American Journal of Biological and Environmental Statistics.

Vol. 6, No. 3, 2020, pp. 43-49. doi: 10.11648/j.ajbes.20200603.12

Received: July 16, 2020; Accepted: August 13, 2020; Published: October 7, 2020

\begin{abstract}
This study investigated heavy metals and physicochemical quality of drinking water used in poultry farms at the Maritime region of Togo. Information was gathered by face-to-face interviewing and samples from different drinking water sources (Wells, drillings and tanks) were collected and analysed for physicochemical parameters such as total hardness, $\mathrm{pH}$, nitrate, sulphate and some heavy metals: $\mathrm{Hg}, \mathrm{Cd}, \mathrm{Cu}, \mathrm{Cr}, \mathrm{Fe}, \mathrm{As}, \mathrm{Ni}, \mathrm{Pb}$ and $\mathrm{Zn}$ using standard methods Atomic Absorption Spectrometer Thermo Electron S series. The results showed that most of poultry farms in Maritime region were located within potential provenances sources of water pollution. These sources comprised agricultural, residential and industrial areas. The analysis indicated that concentrations of the metals were mostly far below the maximum recommended concentration. However, the concentrations of Iron, Cadmium, Lead and Mercury in some of the water samples were higher than the international standard values. Also the concentration of nitrate and sulphate in some water samples were higher than the levels recommended by WHO. The water samples were soft and moderately hard. The $\mathrm{pH}$ of all analysed samples was within the allowable limit. It was concluded that the contamination of drinking water in the poultry farms of the Maritime region of Togo was moderate except in industrial areas which was considerably high.
\end{abstract}

Keywords: Drinking Water, Heavy Metals, Poultry Farms, Maritime Region of Togo

\section{Introduction}

Water is very important in poultry production. It is a vital nutrient, implicated in many aspects of poultry metabolism as it plays an important role in digestion, absorption of food, transportation of nutrient and elimination of waste products. It is also an essential element for cleaning and disinfection. Optimal poultry productivity requires the availability of adequate good quality water supplies. Chicken are able to survive much longer without feed than water [1]. A rule of thumb for water consumption is that the bird consumes from
1.5 to 2 times as much water as it does feed [2]. Water represents between $55-75 \%$ of the weight of a chicken and $65 \%$ of the egg, about $70 \%$ inside the cells and $30 \%$ is in fluid surrounding the cells and in blood [3]. Therefore, the water considered suitable for poultry should be safe for human consumption [3]. Drinking water used in poultry production is sourced from wells, drilling and tanks. Therefore, quality of drinking water is strongly influenced by the quality of corresponding "parent" natural water from which drinking water is sourced [4].

Water contains natural contaminants particularly inorganics from the geological strata through which the water 
flows and to a varying extent, anthropogenic pollution by chemicals [5]. Water is an ideal medium for the proliferation and distribution of harmful components such as heavy metals in poultry farms. In poultry production, poor quality water has detrimental effects on broiler performance and is negatively correlated with body weights as well as immune resistance [6]. In broiler and layers, it has been shown that there was a linear relationship between increasing concentration of lead in drinking water and some detrimental effects such as decreasing water consumption, body weight, egg production, egg weight and increasing the percentage of embryonic mortalities. On the other hand, exposure of poultry to cadmium resulted in decreased body weights and histopathological changes in different chicken tissues [7, 8].

There is scarcity of information on the physicochemical quality and heavy metals contents of the drinking water in the poultry farms, especially in agricultural, industrial and residential areas of the Maritime Region of Togo. Hence, this study was undertaken to determine the physicochemical quality and heavy metals of the drinking water sources.

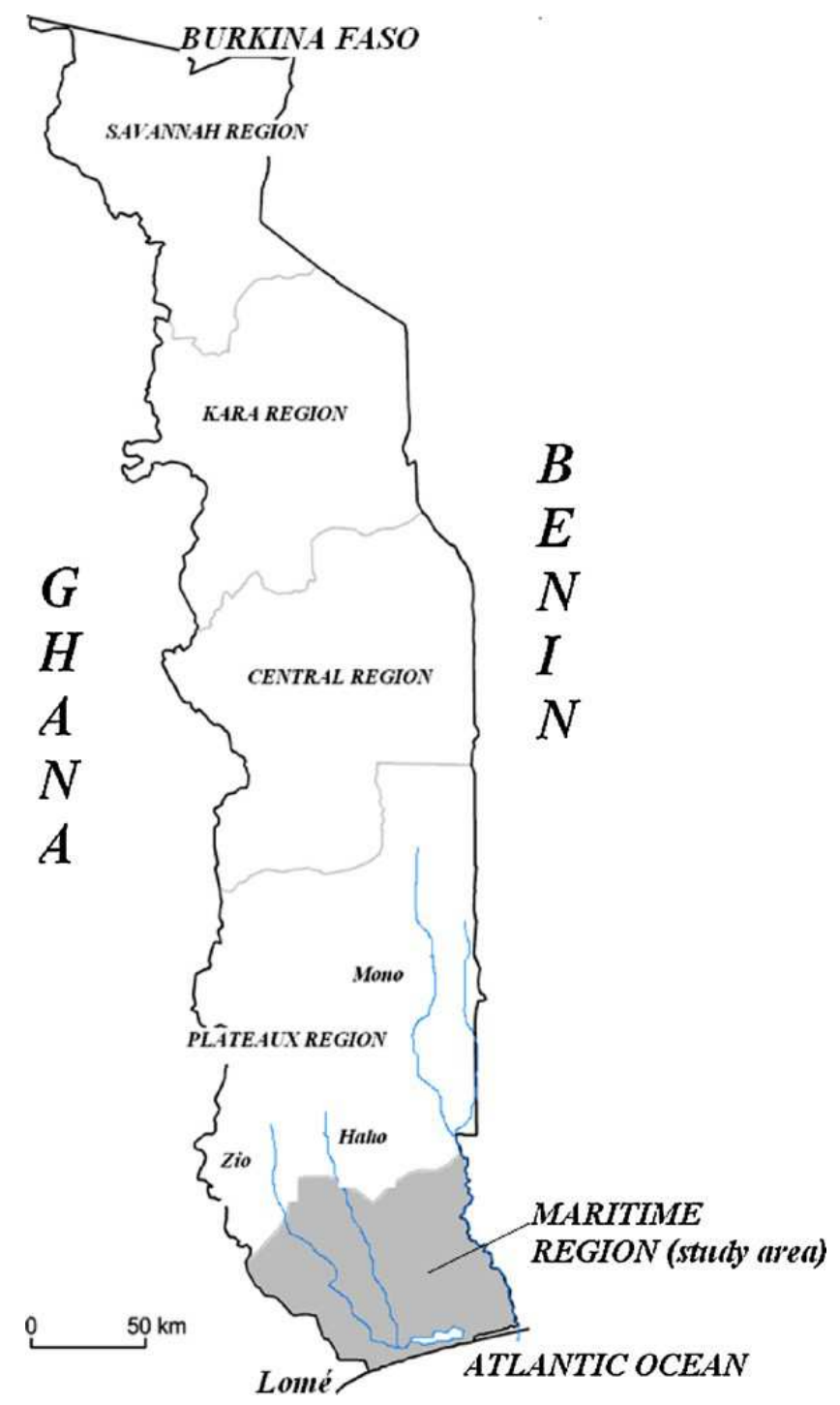

Figure 1. Location of Maritime region-Togo (Koudouvo et al, 2011).

\section{Materials and Methods}

\subsection{The Study Area}

Maritime Region, the Southern region of Togo extends between $6^{\circ} 05^{\prime} \mathrm{N}$ latitude $0^{\circ} 70^{\prime} \mathrm{E}$ longitudes. Limited to the south by Atlantic Ocean, to the north by the Plateaux Region, West by Ghana and East by Benin with estimated area of $6395 \mathrm{Km}^{2}$ and estimated population 2599955 (Figure 1). The climate is subequatorial or Guinean climate with two rainy seasons and two dry seasons. The average temperature is $27^{\circ} \mathrm{C}$ with thermic amplitude variable to $3^{\circ} \mathrm{C}$ to $5^{\circ} \mathrm{C}$ [9]. The Maritime region is the economic hub and industrialized region in Togo. The Region is blessed with abundant natural resources in form of rivers, lakes and lagoons. There are also commercial activities present along the coastline and rapidly growing residential areas. There are hundreds of industries in the Maritime Region. The various industries included mining industries, beverages factories, battery manufacturing, chemical factories, various food stuffs and fruit juice, agriculture and livestock farms, etc. The wastes from these industries directly or indirectly find their way into the surface water, groundwater and creek.

\subsection{General Information of Farms}

Information was gathered from 60 farms by face-to-face interview with the use of specifically designed questionnaires. Questions included in the questionnaires were composed of general farm information, data on water sources used for poultry water consumption, location of the farm and, any additional information that might contribute to drinking water sources contamination such as local industries, urbanization or the use of pesticides in agriculture.

\subsection{Farm Selection and Sampling Procedures}

The work was carried out during March - April 2019. A total of 24 farms were selected. The samples were collected on water sources such as wells, drillings and tanks in different areas at the Maritime region. Samplings sites for drinking water were located in industrial, agricultural and residential areas and were selected as representative for Maritime region: samples S1, S2, S14, S15, S23, and S24 were collected from residential areas, S4, S5, S6, S7, S8, S9, $\mathrm{S} 10, \mathrm{~S} 11, \mathrm{~S} 13, \mathrm{~S} 16$ and $\mathrm{S} 22$ were collected from industrial areas, S3, S1, S17, S18, S19, S20, and S21 were collected from agricultural areas. The samples were drawn from wells, drilling and tanks preferably in the morning (6:00 a.m.). The depth of the wells and drillings arranged between 20 to 80 meters. Water samples were collected using sterile polythene container $(0.51)$, and dropped $6 \mathrm{~N}$ nitric acid to maintain the $\mathrm{pH}$ of the samples less than two for heavy metals and using polythene container (1.5 l) for physicochemical parameters. The major water quality parameters considered were $\mathrm{pH}$, total hardness, sulphates, nitrates and some heavy metals.

\subsection{Heavy Metals and Physicochemical Analysis}

All the analyses were done in laboratory of Environmental 
Toxicology at University of Lomé - Togo.

Heavy metals $(\mathrm{Cd}, \mathrm{Cr}, \mathrm{Cu}, \mathrm{Fe}, \mathrm{Ni}, \mathrm{Pb}$ and $\mathrm{Zn}$ ) were determined by standard methods using Atomic Absorption Spectrometer Thermo Electron S series. Arsenic (As) and mercury $(\mathrm{Hg})$ were determined by generator hydrure thermo Scientific VP 1000 coupled with Atomic Absorption Spectrometer Thermo Electron S series. The metals were estimated in the sample solution by aspirating the sample solution directly into plasma of the instrument. The instrument was standardized for the individual elements. Calibration curve was obtained for every metal ion using standard solution. The minimum concentration of metal that could be detected by the instrument was $10 \mathrm{ppb}$. The total hardness (Calcium/magnesium) were determined by standard methods using Atomic Absorption Spectrometer Thermo Electron $\mathrm{S}$ series. $\mathrm{pH}$ by $\mathrm{pH}$-meter Crison $\mathrm{PH} 25$, electrical conductivity by Knick Portamess 911 and molecular adsorption spectrophotometer - HACH DR 3800 for sulphate and nitrate. The contamination values were calculated using the equation described by Hakanson [10].

\section{Results}

\subsection{Location of Poultry Farms and Types of Water Resources Used for Birds' Consumption}

Data collected from the questionnaire indicated that most of poultry farms in Maritime region were located within potential provenances sources of water pollution. These sources comprised agricultural areas (29 farms), residential areas (17 farms) and industrial areas (14 farms). Water sources used by poultry industry differed between territories and between rural and urban localities. Primary water sources for poultry were: 55 farms used underground water (wells and drillings), 3 farms used tanks (rain water) and 2 farms used town water.

\subsection{Heavy Metals Analysis in Poultry Farms}

As shown in Table 1. The analysis indicated that concentration of the elements were mostly far below the maximum allowable concentration. However, the concentration of cadmium (Cd) in water samples $\mathrm{S} 10>\mathrm{S} 12>\mathrm{S} 11$ were higher than the international standards values. The concentration of mercury $(\mathrm{Hg})$ in samples S1 $>$ S22 $>$ S23 were higher than international standards values. Also, the concentration of iron (Fe) in water sample S22 was higher than the international standards values. The concentration of lead $(\mathrm{Pb})$ in water samples $\mathrm{S} 9>\mathrm{S} 8>\mathrm{S} 1>\mathrm{S} 2>\mathrm{S} 4>\mathrm{S} 7$ were higher than international standards values.

Higher concentration of Cadmium $(\mathrm{Cd})$ and Iron $(\mathrm{Fe})$ were detected in industrial areas where the highest concentration of mercury $(\mathrm{Hg})$ and lead $(\mathrm{Pb})$ were found in residential areas.

Table 1. Concentration of heavy metal $(\mathrm{mg} / \mathrm{L})$ in poultry farms drinking water sources samples.

\begin{tabular}{|c|c|c|c|c|c|c|c|c|c|}
\hline Metals Stations & $\begin{array}{l}\text { AS } \\
(\mathrm{mg} / \mathrm{L})\end{array}$ & $\mathrm{Cd}(\mathrm{mg} / \mathrm{L})$ & $\mathrm{Cr}(\mathrm{mg} / \mathrm{L})$ & $\mathrm{Cu}(\mathrm{mg} / \mathrm{L})$ & $\begin{array}{l}\mathrm{Fe} \\
(\mathrm{mg} / \mathrm{L})\end{array}$ & $\mathrm{Hg}(\mathrm{mg} / \mathrm{L})$ & $\begin{array}{l}\mathrm{Ni} \\
(\mathrm{mg} / \mathrm{L})\end{array}$ & $\mathrm{Pb}(\mathrm{mg} / \mathrm{L})$ & $\begin{array}{l}\mathrm{Zn} \\
(\mathrm{mg} / \mathrm{L})\end{array}$ \\
\hline S1 & 0.002 & ND & 0.042 & 0.0005 & ND & 0.012 & ND & 0.02 & 0.3515 \\
\hline S2 & ND & ND & 0.044 & 0.024 & 0.3736 & 0.008 & ND & 0.02 & 0.1744 \\
\hline S3 & ND & ND & 0.044 & 0.003 & ND & 0.009 & 0,0134 & ND & 0.0091 \\
\hline S4 & ND & ND & 0.031 & 0.009 & 0.0188 & 0.009 & 0.0142 & 0.02 & ND \\
\hline S5 & 0.018 & ND & 0.025 & 0.009 & 2.1931 & 0.009 & ND & ND & ND \\
\hline S6 & 0.003 & ND & 0.023 & 0.021 & 0.1898 & 0.009 & 0.0419 & 0.008 & 0.0822 \\
\hline S8 & 0.001 & 0.001 & 0.032 & 0.003 & ND & 0.009 & ND & 0.04 & ND \\
\hline S9 & 0.001 & 0.006 & 0.025 & 0.010 & ND & 0.009 & ND & 0.05 & 0.1204 \\
\hline $\mathrm{S} 10$ & 0.001 & 0.019 & 0.028 & 0.006 & ND & 0.009 & 0.0025 & ND & 0.0047 \\
\hline S11 & 0.001 & 0.014 & 0.016 & 0.008 & ND & 0.009 & ND & ND & 0.1922 \\
\hline S12 & 0.001 & 0.016 & 0.025 & 0.007 & ND & 0.009 & ND & 0.01 & ND \\
\hline S13 & 0.002 & ND & 0.022 & 0.010 & 0.1158 & 0.009 & 0.0028 & ND & ND \\
\hline S14 & 0.002 & ND & 0.002 & 0.016 & 0.828 & 0.008 & ND & ND & 0.012 \\
\hline S17 & 0.002 & ND & 0.010 & 0.011 & ND & 0.009 & 0.0027 & ND & 0.2253 \\
\hline S18 & 0.002 & ND & 0.015 & 0.003 & 0.5472 & 0.009 & ND & ND & 0.0154 \\
\hline S19 & 0.001 & ND & 0.012 & 0.003 & ND & 0.009 & ND & ND & 0.2741 \\
\hline S20 & 0.003 & ND & 0.008 & ND & ND & 0.008 & 0.0006 & ND & 0.316 \\
\hline $\mathrm{S} 21$ & 0.002 & ND & 0.014 & 0.013 & ND & 0.008 & ND & ND & ND \\
\hline $\mathrm{S} 22$ & 0.015 & 0.0034 & 0.023 & 0.001 & 15.9546 & 0.011 & 0.0117 & ND & ND \\
\hline $\mathrm{S} 23$ & 0.002 & 0.0093 & 0.012 & 0.009 & ND & 0.010 & 0.0148 & ND & ND \\
\hline S24 & 0.003 & 0.0138 & 0.007 & 0.009 & ND & 0.008 & 0.0033 & ND & 0.0341 \\
\hline International Standard [31] & 0,01 & 0,003 & 0,05 & 2 & 2 & 0,006 & 0,07 & 0,01 & 3 \\
\hline
\end{tabular}

\subsection{Physicochemical Analysis in Poultry Farms}

As shown in the Table 2, the concentration of nitrate was higher in S7> S18> S23 $>$ S15 $>$ S9> S24> S16 than international standards value $(50 \mathrm{mg} / \mathrm{L})$ and others concentration was found to be within the prescribed international limits. The sulphate concentration was higher in S3> S8 than International standards value $(250 \mathrm{mg} / \mathrm{L})$ and the others sampling concentration was below the prescribed international limits. The total hardness of all samples were soft and moderately soft. The $\mathrm{pH}$ values were 
acidic for most samples.

Table 2. Concentration of physicochemical parameters $(\mathrm{mg} / \mathrm{L})$ in poultry farms drinking water sources samples.

\begin{tabular}{|c|c|c|c|c|}
\hline Physicochemical Stations & pH & Nitrate & Total hardness & Sulphate \\
\hline S1 & 6.39 & 37.5 & 86.22 & 15 \\
\hline $\mathrm{S} 2$ & 6.38 & 11.7 & 84.38 & 12 \\
\hline S3 & 5.94 & 30.5 & 236.02 & 330 \\
\hline S4 & 6.33 & 66.9 & 55.58 & 6 \\
\hline S5 & 6.37 & 0.331 & 22.70 & 100 \\
\hline S6 & 6.51 & 0.636 & 56.94 & 11 \\
\hline S7 & 5.08 & 193 & 142.82 & 48 \\
\hline S8 & 6.81 & 1.51 & 32.27 & 290 \\
\hline S9 & 6.2 & 57.9 & 54.78 & 1 \\
\hline $\mathrm{S} 10$ & 5.48 & 19 & 59.67 & 1 \\
\hline S11 & 6 & 40.9 & 13.16 & 1 \\
\hline $\mathrm{S} 12$ & 6.46 & 7.4 & 197.05 & 1 \\
\hline $\mathrm{S} 13$ & 6.88 & 39.6 & 2.36 & 1 \\
\hline S14 & 7.01 & 6.22 & 35.76 & 1 \\
\hline S15 & 6.45 & 73.9 & 54.43 & 32 \\
\hline S16 & 6.38 & 51.3 & 14.52 & 32 \\
\hline S17 & 6.84 & 1.75 & 65.85 & 1 \\
\hline S18 & 6.56 & 159 & 51.32 & 18 \\
\hline S19 & 6.65 & 4.3 & 17.96 & 8 \\
\hline S20 & 6.97 & 4.3 & 20.56 & 2 \\
\hline S21 & 6.8 & 145 & 73.59 & 3 \\
\hline S22 & 7.7 & 0.809 & 84.22 & 23 \\
\hline S23 & 6.24 & 158 & 84.64 & 35 \\
\hline S24 & 5.91 & 52.8 & 103.74 & 106 \\
\hline International Standard $[16,31]$ & $6,5-8,5$ & 50 & $0-50$ & 250 \\
\hline
\end{tabular}

\subsection{Heavy Metals Contamination Factor (Cf)}

Contaminant factor $(\mathrm{Cf})$ is the ratio obtained by dividing the concentration of each metal in the water by the background value [10].

$C f=$ Concentration of Heavy metal/Concentration of background

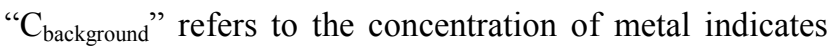
the concentration of metal (of interest). In our study, we applied a modification of this factor with using WHO standard as reference value.

Hakanson (1980) defines four categories of contamination factors:

$\mathrm{Cf}<1$ (Low contamination factor); $1 \leq \mathrm{Cf}<3$ (Moderate contamination factor); $3 \leq \mathrm{Cf}<6$ (considerable contamination factor); $\mathrm{Cf} \geq 6$ (Very high contamination Factor).

As shown in the Table 3, the value of contamination factors varied to $0.01 \mathrm{mg} / \mathrm{L}$ Lower for copper $(\mathrm{Cu})$ to 7.9 $\mathrm{mg} / \mathrm{L}$ higher for iron $(\mathrm{Fe})$.

Many sampling sites had low contamination factors category $(\mathrm{Cf}<1)$ : As $(98 \%), \mathrm{Cr}(100 \%), \mathrm{Cu}(100 \%), \mathrm{Ni}$ (100\%), Zn (100\%), Fe (98\%), Pb (93\%). Some waters samples had moderate contamination factor category $(1 \leq \mathrm{Cf}<3): \mathrm{Hg}(100 \%), \mathrm{Pb}(5 \%)$, As $(2 \%), \mathrm{Cd}(2 \%)$ and $\mathrm{Fe}$ $(1 \%)$.

And some samples sites had considerable contamination factor category $(3 \leq \mathrm{Cf}<6)$ : $\mathrm{Cd}(5 \%)$ and $\mathrm{Pb}(2 \%)$.

Only $\mathrm{Fe}(1 \%)$ of iron was in very high contamination factor $(\mathrm{Cf} \leq 6)$.
Table 3. Contamination factors.

\begin{tabular}{ll}
\hline Metals & Min - Max \\
\hline $\mathrm{AS}$ & $0.1-1,5$ \\
$\mathrm{Cd}$ & $0.1-6.3$ \\
$\mathrm{Cr}$ & $0.1-0.8$ \\
$\mathrm{Cu}$ & $0.00025-0.01$ \\
$\mathrm{Fe}$ & $0.00025-7.9$ \\
$\mathrm{Hg}$ & $0.0008-0.012$ \\
$\mathrm{Ni}$ & $0.0008-0.5$ \\
$\mathrm{~Pb}$ & $0.8-5$ \\
$\mathrm{Zn}$ & $0.003-0.1$ \\
\hline
\end{tabular}

\section{Discussion}

The main aim of this paper was to assess the status of drinking water quality of the poultry farms in the Maritime region of Togo. The results obtained in the present study indicated that most poultry farms in Maritime region were located in agricultural, residential and industrial areas which were potential sources of contaminants such as nitrate, sulphate and heavy metals which can migrate or be discharged into the water sources.

The study revealed that in many areas, the heavy metals in poultry farms water resources were within normal limits except cadmium, mercury, Lead and Iron [31]. Concentration of metals in water samples of the study are presented in Table 1. Metals concentrations in water were found in the following order: $\mathrm{Fe}>\mathrm{Cd}>\mathrm{Pb}>\mathrm{Hg}>\mathrm{As}>\mathrm{Cr}>\mathrm{Ni}>\mathrm{Zn}>\mathrm{Cu}$.

Iron is one of the most abundant metals in the Earth's crust. Its concentration varies in natural fresh waters at levels ranging from 0.5 to $50 \mathrm{mg} / \mathrm{L} \mathrm{[16].} \mathrm{The} \mathrm{concentration} \mathrm{of} \mathrm{Iron}$ in this study varied from 0 to $7.9 \mathrm{mg} / \mathrm{L}$ which was far from 
the international standards $(2 \mathrm{mg} / \mathrm{L})$ [31]. The highest concentration of iron was found in industrial area. The values obtained in this study are comparable to other studies $[13,15$, $17,19]$. The high concentration of iron in industrial area could be attributed to the metal work and mining activities. The primary sources of iron in drinking water are natural geologic sources and corroding distribution system and household pipes. The effects associated with iron contamination can be grouped into two; aesthetic effect and physical effect. The aesthetic effects are the undesirable tastes or odors, iron in quantities greater than $0.3 \mathrm{mg} / \mathrm{L}$ in drinking water can cause unpleasant metallic taste and rust color. Physical effects can lead to blockage or slowing down water flow [16]. The most common problems with iron levels above $0.3 \mathrm{ppm}$ is the growth of iron bacteria that use iron in the water, pipes, tanks, and well casings as nutrient source [17]. The deficiency of iron causes anemia and prolonged consumption of drinking water with high concentration of iron lead to liver disease called haermosiderosis [18, 19].

The cadmium level varied from undetected level to 0.019 $\mathrm{mg} / \mathrm{L}$; with the highest measured at (S10) industrial area. The maximum allowable limit for cadmium was $0.003 \mathrm{mg} / \mathrm{L}$ and some samples were higher than international standards [31]. The value obtained was comparable to the earlier studies [13, $15,17,19]$. The high concentration of cadmium could be linked to the industrial activities, waste disposal and smelting from factories in the environment. Cadmium exposure produces oxidative stress by disturbing the oxidative and anti-oxidative balance of the adult poultry birds. Zinc administration recorded beneficial effects in reduction of cadmium residues in broiler tissues and reduced cadmium toxicity by enhancing the liver and kidney functions and the haematological parameters $[14,15]$.

The concentration of arsenic (As) in the natural water generally ranged between 1 and $2 \mathrm{mg} / \mathrm{L}$, although concentrations may be elevated (up to $12 \mathrm{mg} / \mathrm{L}$ ) in areas containing natural sources [16]. In this study the higher concentration of Arsenic was $0.01 \mathrm{mg} / \mathrm{L}$ at (S5) industrial area; whereas the International standards is $0.01 \mathrm{mg} / \mathrm{L}$ [31]. The high concentration of arsenic in this location could be attributed to the presence of sawmilling, industrial process and animal rearing activates in the area. The value obtained in this study is also comparable to other studies [13, 15, 17, 19].

Chromium $(\mathrm{Cr})$ was detected in all the sampling areas. In this study chromium $(\mathrm{Cr})$ varied from 0.002 to $0.044 \mathrm{mg} / \mathrm{L}$, which was above the international maximum admissible in drinking water $(0.05 \mathrm{mg} / \mathrm{L})$ [31]. And the values obtained in this study are comparable to other studies [13, 15, 17, 19].

Copper $(\mathrm{Cu})$ level varied from 0.0005 to $0.02 \mathrm{mg} / \mathrm{L}$ which was within the limit of International standards (2 mg/L) [31]. In natural waters copper appears due to dissolution of minerals, at around of $1-10 \mu \mathrm{g} / \mathrm{L} \mathrm{[16].} \mathrm{The} \mathrm{value} \mathrm{obtained} \mathrm{is}$ comparable to other studies conducted in other areas $[13,15$, $17,19]$. Overdoses of copper may also lead to neurological complications, hypertension and liver and kidney dysfunctions [11, 12].

In this study, Nickel (Ni) was detected in eleven of the sampling areas with high concentration $0.041 \mathrm{mg} / \mathrm{L}$ in (S6) industrial area, which was below the international standards limit $(0.07 \mathrm{mg} / \mathrm{L})$ [31]. Nickel levels in drinking water were generally low $(<0.05 \mathrm{mg} / \mathrm{L})$. Anthropogenic sources of nickel in water include combustion of fuel or wastes released from industries.

In this study, maximum concentration of zinc was found in water sample in residential area (S1) with $0.3515 \mathrm{mg} / \mathrm{L}$; which was below allowable limit $(3 \mathrm{mg} / \mathrm{L})$ [31]. Zinc is one of the important trace elements that play a vital role in the physiological and metabolic process of many organisms. Nevertheless, higher concentrations of zinc can be toxic to the organism [20]. It plays an important role in protein synthesis and is a metal which shows fairly low concentration in surface water due to its restricted mobility from the site of rock weathering or from natural sources [18]. It is extremely toxic to birds.

The maximum tolerable level of mercury is $0.006 \mathrm{mg} / \mathrm{L}$. In this study, the concentration of mercury varied from 0.008 $\mathrm{mg} / \mathrm{L}$ to $0.012 \mathrm{mg} / \mathrm{L}$. Three water samples showed high level of mercury; which was mostly far from the international standards limit [31]. Mercury as such is volatile but in aquatic environment under the influence of bacteria and fungi, is converted into highly toxic methyl mercury form. These compounds are rapidly absorbed and concentrated by animals.

Poultry can tolerate greater amounts of inorganic mercury than organic methylated form. However, biomethylation of inorganic forms can occur in the environment or in the animal and increase the potential for toxicity. There are conflicting reports concerning the efficacy of selenium to reduce toxicity of mercury [18].

In this study, the maximum level of Lead was found in water sample (S8) with $0.05 \mathrm{mg} / \mathrm{L}$ in residential area; which was higher than maximum allowable limit $(0.01 \mathrm{mg} / \mathrm{L})$ [31]. on the other hands, in urban areas, the major source of Lead is combustion of leaded fuel [21].

Lead is a common cause of poisoning in domestic animals throughout the world. Lead poisoning can occur in all domestic animals including horses, poultry and dogs [22]. Broiler chickens are vulnerable to lead toxicity. Lead or zinc poisoning can happen quickly or build up slowly over time depending on how much of the metal a bird ingests, how much of the toxin is present, and other factors. In broiler chickens, lead poisoning significantly reduced body weight and body weight gain. $200 \mathrm{mg} / \mathrm{Kg}$ diet reduced growth in term of body weight and body weight gain, poor performance and death in animals [24].

$\mathrm{pH}$

The $\mathrm{pH}$ values of all poultry farms analyzed samples are shown in Table 2, it is clear that all analyzed samples had $\mathrm{pH}$ within normal range $(6.5-8.5)$ recommended by WHO [31]. Low $\mathrm{pH}$ value makes the water less palatable, corrode metals parts of watering systems and affect broiler performance and reduce shell quality [25]. However, alkaline water of more than 7.5 could damage equipment and above 8.5 lead to mineral incrustation [28].

In this study, the concentration of nitrate varied from 0.33 
to $193 \mathrm{mg} / \mathrm{L}$. The highest concentration of nitrate $(193 \mathrm{mg} / \mathrm{L})$ was found in industrial area and it was higher than the values recorded by WHO [16].

The concentrations of nitrate in Maritime Region samples were high due to the nature of the rocks and underground reservoir which could be contaminated by the several ways [26]. The values obtained in this analysis are also comparable to the values obtained in other studies [22].

The sulphate concentration varied from $1 \mathrm{mg} / \mathrm{L}$ to 330 $\mathrm{mg} / \mathrm{L}$ in the present study. The high concentration was found in Agricultural area (S3).

A high sulphate in the water might be expected from contamination of with birds' droppings and feed particles. In the analyzed samples, most sulphate compounds originated from the oxidation of sulphate, the presence of shale and the existence of industrial wastes. sulphate is one of the major dissolved constituents in rain water [27]. High concentration of sulphate in drinking water causes a laxative effect when combined with calcium and magnesium, the two most common components of hardness, high sulphate in the study area, mostly due to industrial wastes.

The total hardness varied from 2.36 to $236.02 \mathrm{mg} / \mathrm{L}$ in $\mathrm{S} 3$. According to the classification in Table 4, the total hardness of all samples varied from soft to moderately hard. Total hardness and water quality are related. High level of hardness may be due to proximity and hydraulic connection of groundwater sources to creek [30].

Body weight of broiler chicks increased as hardness, calcium $(\mathrm{Ca})$ and magnesium $(\mathrm{Mg})$ increased [6].

Table 4. ASSESSMENT OF WATER.

\begin{tabular}{ll}
\hline $\mathbf{m g ~ l}^{-1}\left(\mathbf{C a C O}_{3}\right)$ & Assessment \\
\hline $0-50$ & Soft \\
$50-100$ & Moderately soft \\
$100-150$ & Slightly hard \\
$150-200$ & Moderately hard \\
$200-250$ & Hard \\
\hline
\end{tabular}

The contamination factors in poultry farms at Maritime Region of Togo indicated that water samples in the industrial areas was highly contaminated $(\mathrm{Cf} \geq 6)$ with $\mathrm{Fe}$, considerably contaminated $(3<\mathrm{Cf}<6)$ with $\mathrm{Cd}$ and moderately contaminated $(1 \leq \mathrm{Cf}<3)$ with $\mathrm{As}, \mathrm{Hg}$.

In residential areas, the water samples exhibited low contaminated $(\mathrm{Cf}<1)$ with $\mathrm{As}, \mathrm{Cd}, \mathrm{Cr}, \mathrm{Cu}, \mathrm{Fe}, \mathrm{Zn}$; moderately contaminated $(1 \leq \mathrm{Cf}<3)$ with $\mathrm{Hg}$ and considerably contaminated $(3 \leq \mathrm{Cf}<6)$ with $\mathrm{Pb}$.

In case of agricultural areas, all the samples had low contamination $(\mathrm{Cf}<1)$ except $\mathrm{Hg}$ which had moderately contamination factor $(1 \leq \mathrm{Cf}<3)$.

The contamination factors for all metals examined shows that the degree of contamination in water of study areas was low or moderate except in industrial area which was considerably high.

\section{Conclusion}

The results indicated that concentrations of some heavy metals $(\mathrm{Fe}, \mathrm{Cd}, \mathrm{Pb}$ and $\mathrm{Hg}$ ) in some water samples were higher than the International standard maximum allowable limits. The study of water sources in poultry farms showed high concentration of nitrates and sulphate in most of the samples. The contamination factors for all metals examined showed that the degree of contamination of drinking water in poultry farms was low or moderate except in industrial areas which was considerable high. This is an indication of pollution hazards and poor drinking water treatment practices in these poultry farms which, in turn, have implications on poultry health and decreased poultry productivity.

To minimize chemical pollution of poultry water, the following recommendation should be applied:

1. Main water supplies of poultry farms either from the ground or surface water sources should be examined to confirm its fitness for poultry before use.

2. Piped water should run for few minutes before its use to allow sufficient cleaning of distribution systems.

3. Sufficient and equally distribution of drinkers within poultry farms according to density and age of bird should be ensured

4. Protection of poultry water from contamination by frequent cleaning and thorough disinfection of drinkers

5. Health education of owners and farm workers about the hazardous effect of polluted water on poultry production and human consumer's health should be in place.

\section{References}

[1] Scott, M. L., M. C. Nesheim and R. J. Young, 1982. Nutrition of the Chicken. 3rd Edn. Humphrey Press Inc., Geneva, New York.

[2] Kellems, R. O. and D. C. Church, 2002. Livestock Feeds and Feeding. 5th Edn. Prentice Hall, Upper Saddle River, New Jersey.

[3] Robert, A. and Swick, Ph. D. (1998): Water quality and management for poultry. ASA Tech. Bull. Vol. PO41: 1-8.

[4] Tsagarakis, K. P.; Paranychianakis, N. V. and Angelakis, A. N (2003): Aqualibrium European water management between regulations and competition. Country report; Greece, EUKICT-2001-80003.

[5] Fawell, J. and Nieuwenhuijsen, M. J. (2003): Contaminants in drinking water. Environmental pollution and health. British Medical Bulletin. 68: 199-208.

[6] Barton, T. L.; Hileman, L. H. and Nelison, T. S. (1986): A survey of water quality on Arkansas broiler farms and its effect on performance. 36 pp Proc. $21^{\text {st }}$ Natl. Meeting Poultry.

[7] Bokori, J.; Fekete, S.; Glavits, R.; Kadar, I.; Konez, J. and Kovari, L. (1996): Effect of prolonged dietary exposure of broiler chicken to cadmium. Acta Veterinaria Hungarica, 44 (1): 57-74.

[8] Hassan, A. M. A. (1998): Some water pollutants and their effects on immune response to vaccines in poultry. Ph. D. Thesis, Fac. of Vet. Med. Suez Canal Univ. Egypt. 
[9] Fiagan K-A (2014); etude des potentialites aquacoles de la région maritime au Togo, Revue Ivoirienne de Géographie des Savanes, Numéro 2 Juin 2017, ISSN 2521-2125.

[10] Hakanson L., 1980. Ecological risk index for aquatic pollution control. A Sedimentological approach. Water Research, 14 (5): 975-1001. pp. 3539. http://dx.doi.org/10. 15242/IICBE.C0214005.

[11] Larocque, A. C., \& Rasmussen, P. E. (1998). An overview of trace metals in the environment: Mobilization to remediation. Environmental Geology, 33, 85-91.

[12] Krishna, A. K., \& Govil, P. K. (2004). Heavy metal contamination of soil around Pali industrial area, Rajasthan, India. Environmental Geology, 47, 38-44.

[13] McMurtry, Gary M, Wiltshire, Jhon C, Kauahikaua, et al. (1995) Heavy Metal Anomalies in Coastal Sediments of Oahu, Hawaii. Pacific Sci 49: 452-470.

[14] Kant C. A., Meijer G. A. L., Animal Feed Science and Technology, 2007, 133 (1-2): 84-108.

[15] Neveen H. I. Abo El -Enaen and Reham Reda. 2011. Study of the zinc effect on the cadmium pollution in poultry. pp. 121133.

[16] WHO (2003) Nitrate and nitrite and Chloride in drinkingwater. Background document for preparation of WHO Guidelines for drinking-water quality. Geneva, World Health Organization (WHO/SDE/WSH/03.04/56).

[17] Oyeku, O. T \& Eludoyin, A. O. 2010. Heavy metal contamination of ground water resources in a Nigerian urban settlement. African Journal of Environmental Science and Technology, 4 (4): 201-214.

[18] Rajappa, B., Manjappa, S \& Puttaiah, E. T. 2010. Monitoring of heavy metal concentration in groundwater of Hakinaka Taluk, India. Contemporary Engineering Sciences, 3 (4): 183190.

[19] Bhaskar, C. V., Kumar, K \& Nagendrappa, G. 2010. Assessment of heavy metals in water samples of certain locations situated around Tumkur, Karnataka, India', viewed 12 June 2010, http://www.indiaenvironmentportal.org.in//Assessment $\%$ 20 of $\% 20$ heavy $\% 20$ metals $\% 20$ in $\% 20$ water $\% 20$ samples.
[20] Rajkovic, M. B., Lacnjevac, C. M., Ralevic, N. R., Stojanovic, M. D., Toskovic, D. V., Pantelic, G. K., Ristic, N. M \& Jovanic, S. 2008. Identification of metals (heavy and radioactive) in drinking water by indirect analysis method based on scale tests. Sensors, 8: 2188-2207. http://dx.doi.org/10.3390/s8042188

[21] Soylak, M. and Elci, L. (2000): Solid phase extraction of trace metal ions in drinking water samples from KayseriTurkey. J. Trace. Microprobe Tech. (18): 397.

[22] Khan MSH, Mostofa M, Jahan MS, Sayed MA \& Hossain MA (2008). Effect of garlic and Vitamin-B complex in lead acetate induced toxicities in mice. Bangladesh Journal of Veterinary Medicine, 6 (2): 203-210.

[23] Erdogan Z, Erdogan S, Aksu T \& Baytok E (2005). The effect of dietary lead exposure and ascorbic acid on performance, lipid peroxidation status and biochemical parameters of broilers. Turkey Journal of Veterinary and Animal Science, 29: 1053-1059.

[24] Bakalli, R. I., I. G. Presti, and W. L. Raglang, 1995. The magnitude of lead toxicity in broiler chickens. Vet. Hum. Toxicol. 37: 17-19.

[25] Keshavarz, k. (1987): Proper water management for poultry. Poult. Digest, Jan. 12-22.

[26] Spalding, R. F., and M. E. Exner, (1993) Occurrence of Nitrate in Groundwater-A Review, Journal of Environmental Quality, 22, pp. 392-402.

[27] Remade, F., (1987) Ecotoxicology. Third edition. Chichester, John Wiley \& Sons.

[28] Lack, F. (1988): Management of water systems. Poult. Int. June, 49-50.

[29] Akoto, O. and Adiyiah, J. (2007): Chemical analysis of drinking water from some communities in the Brong Ahafo region. Int. J. Environ. Sci. Tech. 4 (2): 211-214.

[30] Naik, P. K., Dehury, B. N., \& Tiwari, A. N. (2007). Groundwater pollution around industrial area in the costal stretch of Maharashtra state, India. Environmental Monitoring and Assessment, 132 (1-3), 207-233.

[31] WHO (2011) Guidelines for Drinking-water Quality. Fourth edition. 